\title{
PEMODELAN DEBIT SETENGAH BULANAN PADA DAS TIDAK BERPENCATAT DENGAN MENGGUNAKAN MODEL MOCK (Studi Kasus di DAS Juwet Gunungkidul, D.I. Yogyakarta)
}

\author{
Ahmad Cahyadi dan Emilya Nurjani \\ Jurusan Geografi Lingkungan Fakultas Geografi Universitas Gadjah Mada \\ Email: ahmadcahyadi@geo.ugm.ac.id
}

\begin{abstract}
Analisis ketersediaan air di suatu DAS merupakan suatu yang sangat penting. Keterdapatan data ketersediaan air di suatu DAS dapat digunakan untuk melakukan perencanaan pemanfaatan sumberdaya di dalam DAS. Namun demikian, tidak semua DAS memiliki data ketersediaan air disebabkan karena tidak adanya stasiun pengamat aliran sungai (SPAS). Oleh karenanya diperlukan suatu upaya untuk mengatasi permaslaahan tersebut, diantara dengan melakukan perkiraan ketersediaan air di suatu DAS dengan menggunakan pemodelan hidrologi. Penelitian ini bertujuan untuk mengatahui ketersediaan air di Sub DAS Juwet dengan menggunakan Model Mock. Data yang digunakan dalam penelitian ini meliputi data hujan, suhu, data topografi lokasi kajian, penutup/penggunaan lahan, tanah dan data pencatatan tinggi muka air (dikonversi menjadi debit) selama minimal satu tahun. Hasil analisis yang telah dilakukan menunjukkan bahwa rerata setengah bulanan ketersediaan air di Sub DAS Juwet adalah sebesar $13,84 \mathrm{~m}^{3} /$ detik, sedangkan rerata total ketersediaan air selama satu tahun adalah $430.621 .920 \mathrm{~m}^{3} /$ tahun. Hasil ini memiliki kesesuaian dengan hasil pencatatan yang ditunjukkan dengan nilai t hasil analisis uji t lebih kecil dibanding $\mathrm{t}$ tabel pada derajat kepercayaan $80 \%$.
\end{abstract}

Kata Kunci: Pemodelan, Debit Setengah Bulanan, Ketersediaan Air, DAS Tidak Berpencatat, Model Mock

\section{Pendahuluan}

Air merupakan bagian penting dalam kehidupan manusia (Sudarmadji dkk, 2012). Telah banyak peradaban termashur di dunia yang berkembang di sekitar sumber air seperti sungai dan danau (Sunjoto, 2012). Selain itu, tanpa keberadaan air manusia tidak akan mampu menjalankan kehidupannya. Namun demikian, air tidak selalu terdapat di semua tempat di permukaan bumi, serta seringkali tidak terdapat sepanjang waktu (Cahyadi dkk, 2011).

Daerah Aliran Sungai (DAS) merupakan satu kesatuan hidrologi dan ekosistem yang mampu menangkap, menyimpan dan mengalirkan air, sedimen serta nutrien dan unsur hara. Antara satu DAS dengan DAS yang lain dibatasi oleh pembatas topografi berupa igir perbukitan atau pegunungan. DAS merupakan sebuah pendekatan yang digunakan untuk menganalisis prosesproses yang terkait dengan siklus hidrologi di daratan. Asumsi yang digunakan dalam analisis hidrologi dengan satuan analisis DAS adalah bahwa batas topografi sama dengan batas hidrologi, air yang jatuh di dalam DAS semua dikeluarkan melalui satu outlet dan DAS merupakan sistem independen yang tidak mendapatkan input air dari DAS yang lain. Meskipun demikian, sebagai sebuah penyederhanaan dari suatu proses alam yang rumit, maka DAS tentunya memiliki beberapa kelemahan (Asdak, 2007). Namun demikian, dalam kajian berbasis DAS, kelemahan itu dapat diabaikan.

Sebagai sebuah sistem hidrologi yang independen, maka analisis ketersediaan air di suatu DAS merupakan hal yang sangat penting. Hal ini untuk mendukung upaya-upaya yang dilakukan manusia dalam perencanaan dan pengelolaan pemenuhan air bersih, pembuatan dan perawatan bangunan air, analisis potensi air untuk peningkatan produksi sektor pertanian dan peternakan, serta untuk perencanaan dan pengelolaan pemenuhan energi listrik. Namun demikian, keterbatasan data pencatatan debit air sungai masih sangat terbatas, sehingga analisis ketersediaan air pada suatu DAS tanpa pencatat aliran sungai (berupa stasiun pencatat aliran sungai atau SPAS) sulit untuk dilakukan.

Penelitian ini bertujuan untuk melakukan analisis ketersediaan air pada suatu DAS yang tidak berpencatat. Studi kasus dilakukan di DAS Juwet, Kabupaten Gunungkidul. Penelitian ini menggunakan Model Mock. Penelitian ini menghasilkan debit setengah bulanan dengan probabilitas $80 \%$. 


\section{Metode Penelitian}

\section{Sumber Data}

Semua sumber data yang digunakan dalam perhitungan debit limpasan Metode Mock adalah data sekunder. Data yang digunakan meliputi data curah hujan harian, temperatur udara bulanan, luas DAS, letak lintang, penggunaan lahan, data pencatatan debit aliran sungai selama satu tahun dan koefisien tanaman di DAS Juwet. Data curah hujan dihitung dengan menggunakan poligon tiesen berdasarkan letak dan curah hujan pada beberapa stasiun pencatat hujan. Temperatur udara dihitung dengan menggunakan konversi Mock dengan berdasarkan suhu yang tercatat di Stasiun Klimatologi Playen. Luas DAS, penggunaan lahan, dan letak lintang diperoleh dari data yang diambil dari peta Rupa Bumi Indonesia lembar Jabung dan Wonosari skala 1:25.000 terbitan BAKOSURTANAL.

\section{Metode Perhitungan}

a. Perhitungan Hujan Rata-rata Wilayah

Perhitungan hujan rerata wilayah dilakukan dengan isohyet. Curah hujan pada masingmasing stasiun yang digunakan dihitung data setengah bulannannya. Hasil tersebut kemudian digunakan untuk menentukan nilai curah hujan setengah bulanan dengan probabilitas $80 \%$. Hasil tersebut kemudian dibuat 24 isohyet yang masing-masing isohyet menunjukkan curah hujan setengah bulanan dengan probabilitas $80 \%$.

\section{b. Perhitungan Suhu}

Penentuan suhu digunakan untuk menghitung besarnya evapotranspirasi. Data suhu untuk masing-masing stasiun yang tidak memiliki pencatat suhu hasilkan dengan menggunakan rumus Mock (1972) seperti yang digunakan oleh Rahmalia (2010) sebagai berikut:

\section{Keterangan:}

$$
T=0,006\left(Z_{1}-Z_{2}\right){ }^{\circ} \mathrm{C}
$$

$\mathrm{T} \quad$ = Beda temperatur udara antara $\mathrm{Z}_{1}$ dan $\mathrm{Z}_{2}$

$Z_{1} \quad=$ Elevasi tempat stasiun koreksi (Stasiun Klimatologi Playen)

$\mathrm{Z}_{2} \quad$ = Elevasi tempat stasiun terkoreksi (median elevasi DAS Juwet)

c. Evaporasi Potensial

Perhitungan evaporasi potensial dilakukan dengan menggunakan rumus Thornthwaite (Sosrodarsono, 1977) sebagai berikut:

$$
\mathrm{EP}=1,62\left(\frac{10 \cdot t}{I}\right)^{a}
$$

Keterangan :

$\mathrm{EP} \quad=$ evapotranspirasi potensial (cm/bulan)

$\mathrm{C}=$ koefisien yang tergantung dengan letak lintang

$\mathrm{t}=$ suhu rerata bulanan $\left({ }^{\circ} \mathrm{C}\right)$

a $\quad=$ koefisien yang dihitung dengan rumus:

$$
a=\left(675 \cdot 10^{-9}\right) \cdot I^{3}-\left(771 \cdot 10^{-7}\right) \cdot I^{2}+\left(179 \cdot 10^{-4}\right) \cdot 1+0,492
$$

I = Indeks panas tahunan, yang ditentukan dengan rumus :

$$
\mathrm{I}=\sum_{m=1}^{12}\left(\frac{t}{5}\right)^{1,51}
$$

d. Perhitungan Debit Limpasan

Perhitungan debit limpasan menggunakan Metode Mock dilakukan dengan menggunakan system tata buku. Evapotranspirasi actual dihitung dengan rumus:

$$
\mathrm{ET}_{0}=\mathrm{CF} \times \mathrm{Ep}
$$

Keterangan: $\quad \mathrm{ET}_{0}=$ Evaporasi Aktual $(\mathrm{mm} / \mathrm{bulan})$

CF $\quad=$ Koefisien Tanaman $/ \mathrm{Kc}$

$\mathrm{Ep} \quad=$ evaporasi Potensial $(\mathrm{mm} /$ bulan$)$ 
Perhitungan surplus air (water surplus/ WS)dilakukan dengan rumus:

$$
\begin{aligned}
& \text { WS }=\left(\mathbf{P}-\mathrm{ET}_{0}\right)-\Delta \mathrm{Sm} \\
& \text { Keterangan: WS = Surplus Air ( } \mathrm{mm} / \mathrm{bulan} \text { ) } \\
& \mathrm{ER} \quad=\text { Excess Rainfall }=\mathrm{P}-\mathrm{ET}_{0} \\
& \left.\mathrm{ET}_{0} \quad=\text { Evaporasi Aktual ( } \mathrm{mm} / \mathrm{bulan}\right) \\
& \mathrm{P} \quad=\text { Curah Hujan ( } \mathrm{mm} / \text { bulan) } \\
& \Delta \mathrm{Sm}=\text { Selisih kandungan airtanah ( } \mathrm{mm} / \mathrm{bulan} \text { ) } \\
& =\text { SMC }- \text { ISM } \\
& \text { ISM = Kelembaban Tanah Awal (mm) } \\
& \mathrm{SMC}=\text { Kapasitas Lapang }(\mathrm{mm})
\end{aligned}
$$

Besarnya infiltrasi, simpanan airtanah, debit limpasan langsung, dan aliran dasar dirumuskan sebagai berikut:

- Infiltrasi pada musim kemarau $\left(\mathrm{l}_{\mathrm{k}}\right)$

- Infiltrasi pada musim penghujan ( $(\mathrm{h})$

- Limpasan Langsung (DRO)

- Simpanan Airtanah (GWS)

- Aliran Dasar (BF)

- Debit Limpasan Total (TRO)

$$
\begin{aligned}
& =\text { DIC } x \text { WS } \\
& =\text { WIC } x \text { WS } \\
& =\text { WS }-I \\
& =[0,5 \times(1+k) \times I]+(k x I G W S) \\
& =I-(G W S-I G W S) \\
& =B F+\text { DRO }
\end{aligned}
$$

Keterangan: $\quad \mathrm{I}=$ Infiltrasi $(\mathrm{mm} /$ bulan $)$

DIC = Koefisien infiltrasi pada musim kemarau

WIC = Koefisien infiltrasi pada musim penghujan

IGWS = Initial Groundwater Storage ( $\mathrm{mm} /$ bulan)

$\mathrm{k} \quad=$ Koefisien Resesi Airtanah

Berdasarkan perhitungan yang telah dilakukan di atas, kemudian debit limpasan total seluruh DAS dapat dihitung dengan menggunakan rumus:

$$
Q=\frac{A \times \operatorname{TRO} \times 1.000}{N \times 86400}
$$

Keterangan: $\quad$ Q = Debit Limpasan DAS $\left(\mathrm{m}^{3} / \mathrm{s}\right)$

$$
\begin{array}{ll}
\mathrm{A} & =\text { Luas DAS }\left(\mathrm{km}^{2}\right) \\
\mathrm{TRO} & =\text { Limpasan Total }(\mathrm{mm} / \text { bulan }) \\
\mathrm{N} & =\text { Jumlah hari dalam satu bulan }
\end{array}
$$

Perhitungan ketersediaan air dengan model Mock didahului dengan menentukan faktor kendala Mock. Faktor ini diperoleh dengan melakukan analisis hasil pencatatan debit sungai selama satu tahun yang kemudian dioleh dengan program Solver untuk menentukan nilai faktor kendala yang paling optimal. Faktor kendala ini mewakili karakteristi DAS yang dikaji.

\section{Kondisi Wilayah Kajian}

\section{Letak, Luas, dan Batas Wilayah Penelitian}

Wilayah penelitian yang digunakan adalah Daerah Aliran Sungai (DAS) Juwet yang secara administratif masuk ke dalam wilayah Kabupaten Gunungkidul, Daerah Istimewa Yogyakarta. Berdasarkan peta rupa bumi Indonesia (RBI) skala 1: 25.000 Tahun 1999 lembar 1408-311 (Wonosari), lembar 1408-313 (Jabung), dan lembar 1408-314 (Cawas), wilayah DAS Juwet meliputi tiga kecamatan, yaitu Kecamatan Gedangsari, Kecamatan Patuk, dan Kecamatan Nglipar. Wilayah DAS Juwet di Kecamatan Gedangsari meliputi tiga desa yaitu Desa Hargomulyo, Desa Mertelu dan Desa Ngalang. Wilayah DAS Juwet di Kecamatan Nglipar mencakup tiga desa yaitu Desa Kedungpoh, Desa Pengkol dan Desa Pilangrejo, sedangkan wilayah DAS Juwet di Kecamatan Patuk hanya mencakup sebagian dari Desa Nglegi. Peta Administrasi DAS Juwet ditunjukkan oleh Gambar 1. 


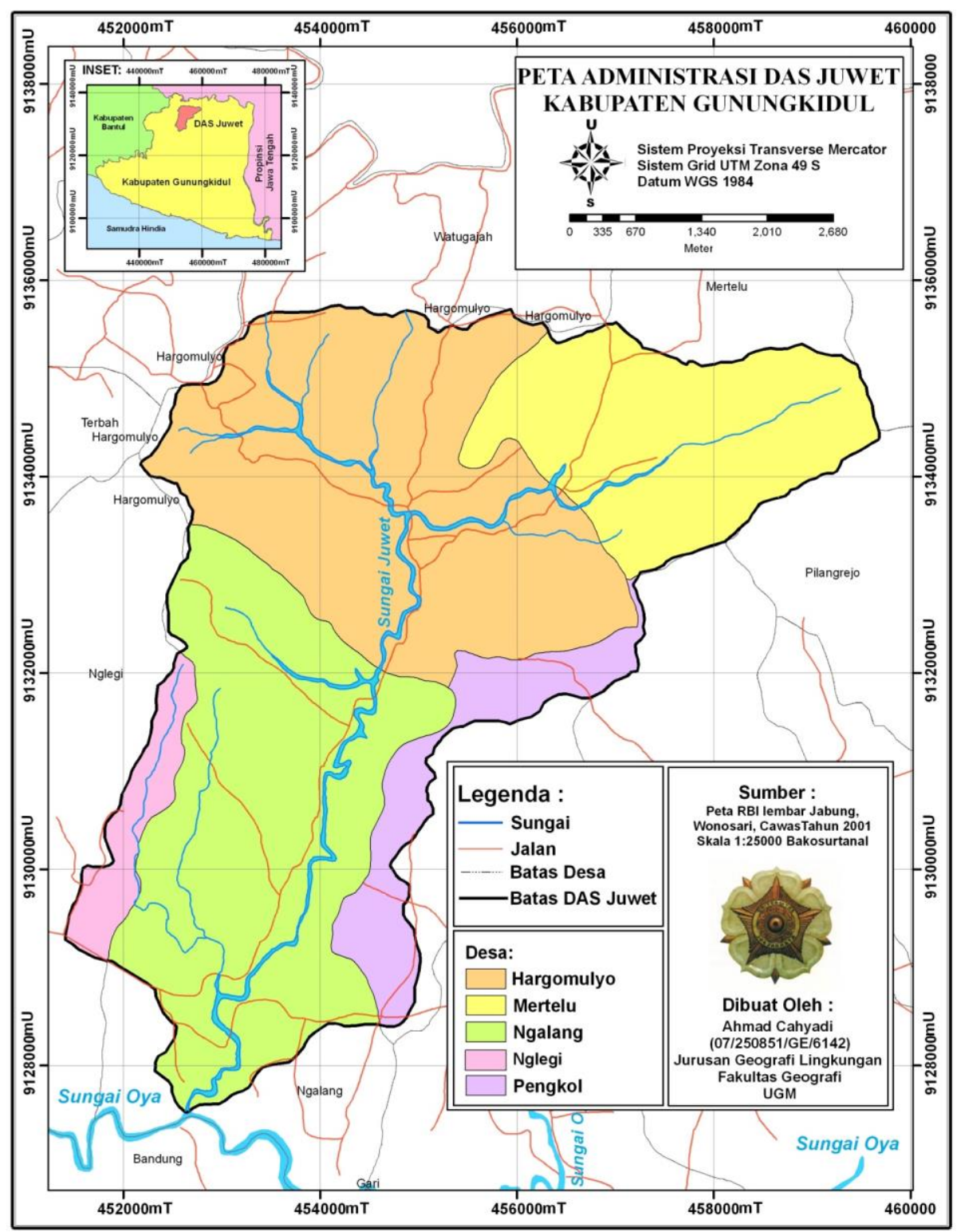

Gambar 1. Peta administrasi DAS Juwet

Berdasarkan hasil analisis dengan menggunakan sistem informasi geografis (SIG), diketahui bahwa luas DAS Juwet adalah $3.263,1$ hektar (ha). Secara astronomis DAS Juwet terletak pada koordinat 7049'49" LS - 7052'16" dan pada koordinat 110 $34^{\prime} 13^{\prime \prime}$ BT - 110 $35^{\prime} 3^{\prime \prime}$ BT, atau pada sistem proyeksi Universal Transverse Mercator (UTM) terletak pada $451.242 \mathrm{mT}$ - $459.687 \mathrm{mT}$ dan pada 9.127.451 $\mathrm{mU}-9.135 .470 \mathrm{mU}$.

Batas wilayah DAS Juwet adalah sebagai berikut:
a. Batas sebelah Timur
: DAS Dondong
b. Batas sebelah Selatan :
: Sungai Oyo
c. Batas sebelah Barat
: DAS Widoro
d. Batas sebelah Utara
: DAS Dengkeng

\section{Tanah Wilayah Penelitian}

Tanah menurut Soil Survei Staff (1998) adalah suatu benda alam yang tersusun dari padatan (bahan mineral dan bahan organik), cairan dan gas, yang menempati permukaan daratan, menempati ruang, dan dicirikan oleh salah satu atau kedua cirri berikut; (1) horison-horison atau lapisan-lapisan yang dapat dibedakan dari bahan asalnya sebagai suatu hasil dari proses penambahan, kehilangan, pemindahan, serta transformasi energi dan materi, dan atau (2) berkemampuan untuk mendukung tanaman berakar di dalam suatu lingkungan alami dapat hidup. Pembentukan tanah yang terus 
berlangsung di alam akan menyebabkan terjadinya perkembangan tanah yang kemudian memiliki ciri-ciri dan sifat-sifat tertentu. Hal tersebut kemudian digunakan untuk dasar klasifikasi tanah.

DAS Juwet memiliki empat ordo tanah yaitu Entisols, Inceptisols, Vertisols dan Alfisols.Berdasarkan peta tanah pada Gambar 2. diketahui bahwa terdapat beberapa bagian DAS Juwet yang berupa singkapan batuan. Hal ini terjadi pada Formasi Nglanggran yang terletak pada pegunungan struktural terkikis kuat yang memiliki kemiringan lereng yang curam sampai sangat curam.Tanah tidak berkembang pada lokasi tersebut karena erosi yang terjadi sangat tinggi.Entisols berasal dari kata recent (baru saja) dan sols (solum atau tanah). Entisol digunakan untuk menyebut tanah yang baru saja terbentuk sehingga tidak memiliki horison genetik alamiah atau belum mengalami perkembangan.Tanah ini memiliki sifat yang masih sangat dipengaruhi oleh bahan induknya. Horison pada tanah ini adalah horisonA dan C. Sub ordo tanah ini yang ditemukan di DAS Juwet adalah Lithic Ustorthents. Tanah ini memiliki ketebalan kurang dari $30 \mathrm{~cm}$.

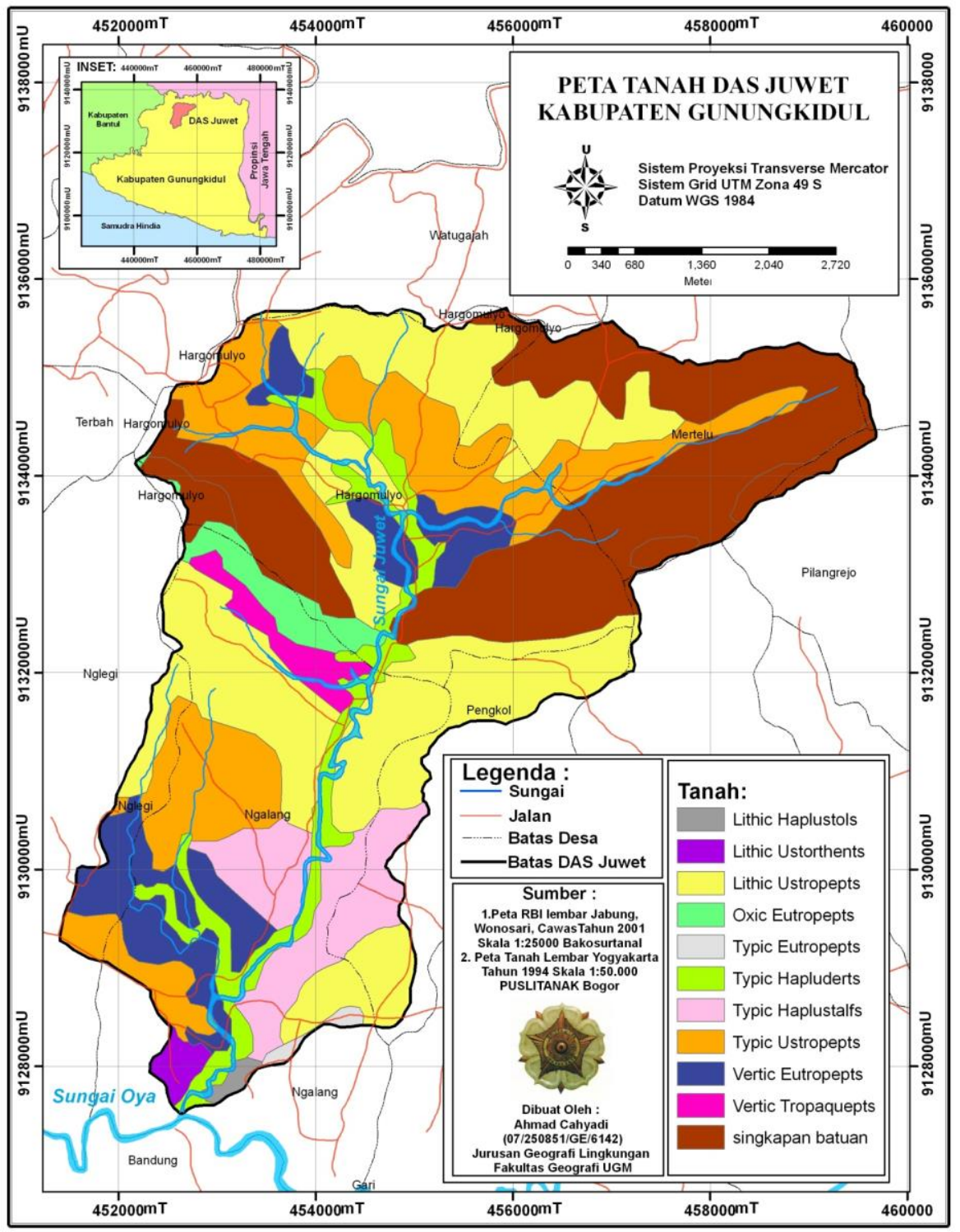

Gambar 2. Peta tanah skala semi detail DAS Juwet

Inceptisols berasal dari kata inceptum (permulaan) dan sols (solum atau tanah). Tanah ini baru mulai berkembang sehingga mulai terbentuk horison B kambik (Bw). Sub Grup dari Inceptisols yang terdapat di DAS Juwet adalah Lithic Ustropepts, Oxic Eutropepts, Tipic Eutropepts, Typic Ustropepts, Vertic Eutropepts dan Vertic Tropaquepts. Ordo tanah Inceptisols merupakan ordo tanah yang paling luas di DAS Juwet.

Vertisols adalah tanah yang dicirikan dengan keberadaan bidang kilir.Tanah ini memiliki kembang kerut yang tinggi, sehingga pada saat terbentuk rekahan-rekahan (saat tanah 
mengembang) tanah pada bagian atas dapat masuk ke dalam rekahan tersebut atau sering disebut dengan istilah pembalikan (invert).Sub Grup tanah ini yang terdapat di DAS Juwet adalah Typic Hapludert yang terdapat di sekitar aliran Sungai Juwet.

Alfisols adalah tanah yang telah berkembang dengan ciri khusus berupa epipedon plagen, endopedon argilik dan kejenuhan basa $>50 \%$. Tanah ini memiliki kandungan alumunium dan besi yang tinggi dan memiliki kesuburan tanah yang tinggi. Sub Grup dari Alfisols yang terdapat di DAS Juwet adalah Lithic Haplustalfs dan Typic Haplustalfs.

\section{Curah Hujan}

Curah hujan wilayah ditentukan berdasarkan data yang tercatat pada alat penakar hujan yang terdapat pada suatu stasiun hujan.Namun demikian, tidak ada stasiun hujan yang terdapat di dalam DAS Juwet. Curah hujan wilayah di DAS Juwet dihitung berdasarkan dengan data yang terdapat pada stasiun-stasiun di atas dengan metode isohyet (Gambar 3). Isohyet adalah garis yang menghubungkan wilayah dengan curah hujan yang sama. Berdasarkan metode tersebut diperoleh nilai curah hujan rerata tahunan sebesar $1.660 \mathrm{~mm} /$ tahun.

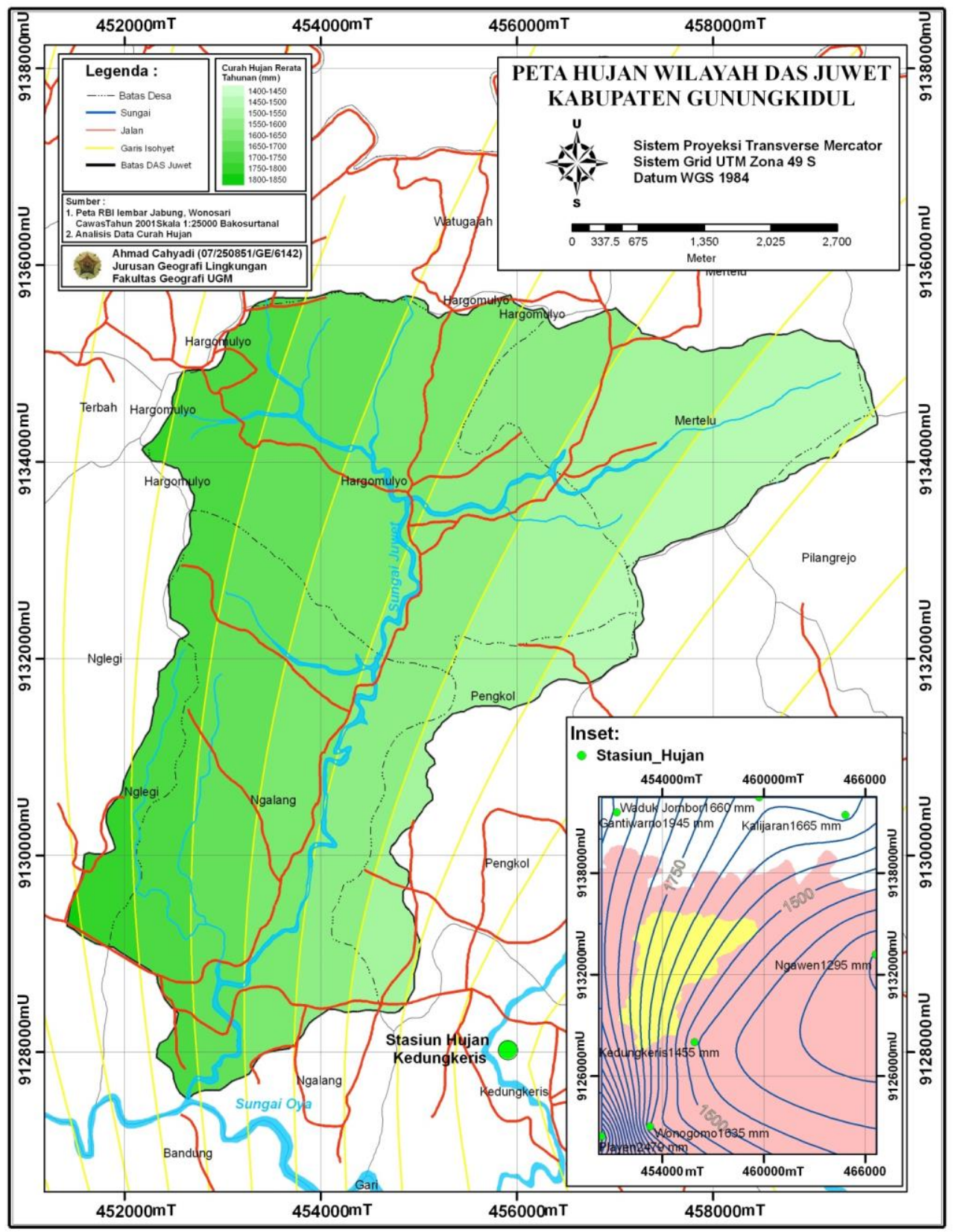

Gambar 3. Peta Isohyet Tahunan Wilayah DAS Juwet 


\section{Penggunaan Lahan}

Penggunaan lahan di DAS Juwet meliputi semak belukar, sawah tadah hujan, kebun campuran, tegalan, dan permukiman. Tegalan merupakan penggunaan lahan yang paling luas yakni 2.372,6 hektar atau 72,7 \% dari total luas dari DAS Juwet (Tabel 1). Dan Gambar 4. Penggunaan lahan ini menenmpati lereng-lereng perbukitan bahkan sampai dengan puncak perbukitan. Sawah tadah hujan menempati luas yang paling banyak kedua, yakni mencapai 405,4 hektar atau $12,4 \%$. Persawahan ini menempati Cekungan Hargomulyo dan serta bagian hilir DAS Juwet yang relatif datar. Berdasarkan macam dan luas penggunaan lahannya, dapat disimpulkan bahwa hampir seluruh wilaya DAS Juwet sudah dikelola atau dimanfaatkan masyarakat untuk memenuhi kebutuhannya. Hal ini nampak dari luasan semak belukar (lahan non-budidaya) yang hanya 186 hektar atau 5,7\% dari luas DAS Juwet.

Tabel 1. Penggunaan lahan di DAS Juwet

\begin{tabular}{|l|r|r|}
\hline \multicolumn{1}{|c|}{ Penggunaan lahan } & \multicolumn{1}{c|}{ Luas (ha) } & \multicolumn{1}{c|}{ \% Luas } \\
\hline Semak Belukar & 186 & 5,7 \\
\hline Kebun Campuran & 32,1 & 1,0 \\
\hline Tegalan & 2372,6 & 72,7 \\
\hline Sawah Tadah Hujan & 405,4 & 12,4 \\
\hline Permukiman & 267 & 8,2 \\
\hline Jumlah & $\mathbf{3 2 6 3 , 1}$ & $\mathbf{1 0 0 , 0}$ \\
\hline
\end{tabular}

Sumber: Anaslis sistem informasi geografis

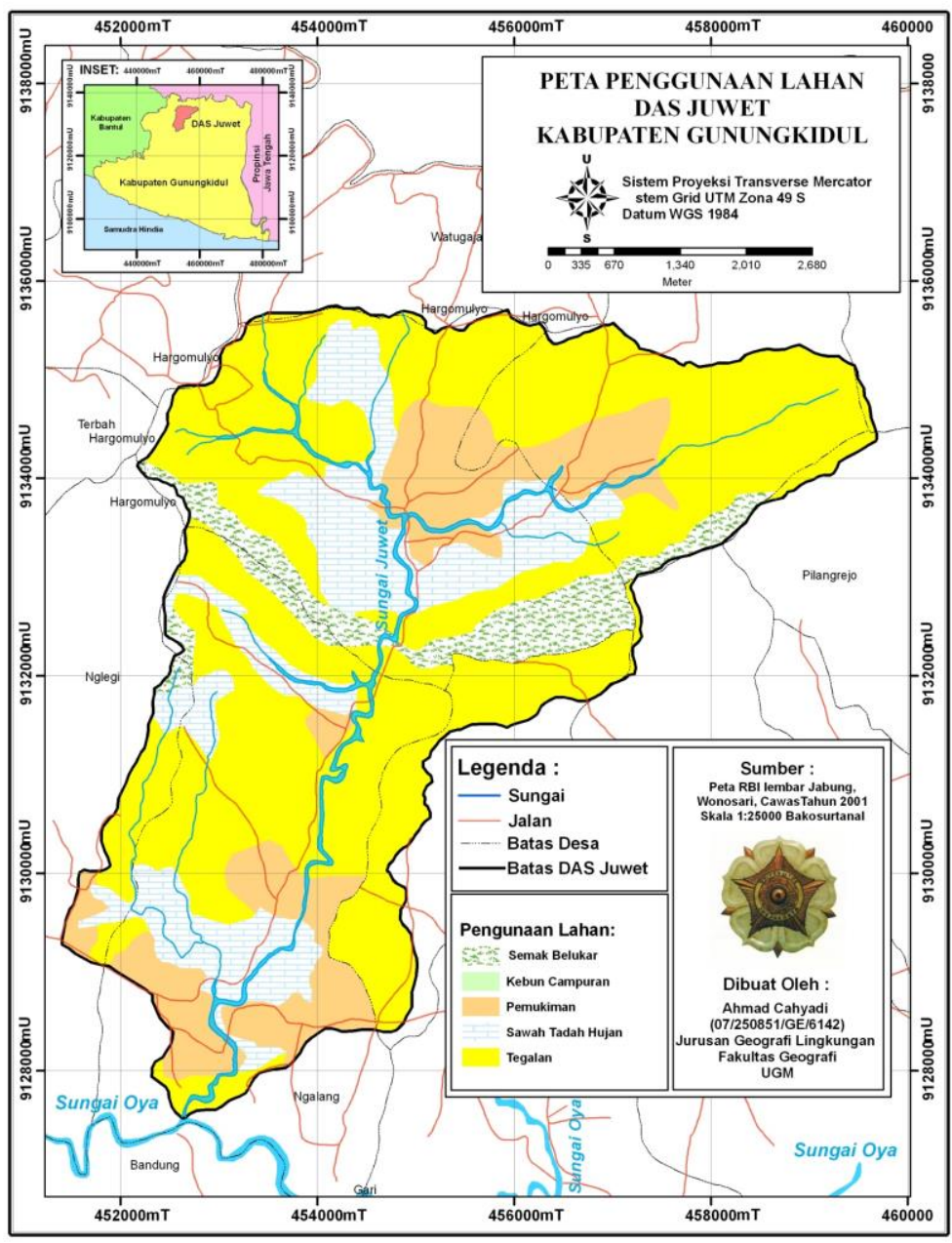

Gambar 4. Peta penggunaan lahan DAS Juwet 


\section{Hasil penelitian dan pembahasan}

Hasil perhitungan hujan wilayah DAS Juwet menunjukkan bahwa hujan maksimun terjadi pada setengah bulan kedua dari Bulan Januariyakni $210 \mathrm{~mm}$, sedangkan hujan paling rendah terjadi pada Bulan Agustus sampai setengah bulan pertama Bulan September yakni tidak ada kejadian hujan. Analisis terhadap hujan dan evapotranspirasi aktual yang ditunjukkan pada Gambar 5. Gambar tersebut menunjukkan bahwa defisit air secara meteorologis di DAS Juwet terjadi pada setengah bulan kedua Bulan Mei, setengah bulan pertama Bulan Juni, dan setengah bulan kedua Bulan Juli sampai dengan setengah pertama Bulan Oktober. Kondisi ini dapat dicirikan dengan nilai curah hujan yang lebih kecil dibandingkan dengan besarnya evapotranspirasi aktual pada waktu yang sama.

Tabel 2. Curah hujan dan evapotranspirasi DAS Juwet

\begin{tabular}{|c|c|c|c|c|c|c|c|}
\hline Bulan & $\begin{array}{c}\text { Tengah } \\
\text { Bulan }\end{array}$ & $\begin{array}{c}P \\
(\mathrm{~mm})\end{array}$ & $\begin{array}{l}\text { AET } \\
(\mathbf{m m})\end{array}$ & Bulan & $\begin{array}{c}\text { Tengah } \\
\text { Bulan }\end{array}$ & $\begin{array}{c}\mathbf{P} \\
(\mathrm{mm})\end{array}$ & $\begin{array}{c}\text { AET } \\
(\mathrm{mm})\end{array}$ \\
\hline \multirow{2}{*}{ Januari } & I & 90 & 12,5 & \multirow{2}{*}{ Juli } & 1 & 11 & 5,3 \\
\hline & II & 210 & 12,5 & & II & 1 & 4,5 \\
\hline \multirow{2}{*}{ Februari } & 1 & 147 & 11,2 & \multirow{2}{*}{ Agustus } & 1 & 0 & 4,3 \\
\hline & II & 130 & 11,2 & & II & 0 & 4,6 \\
\hline \multirow{2}{*}{ Maret } & 1 & 95 & 11,6 & \multirow{2}{*}{ September } & 1 & 0 & 4,8 \\
\hline & II & 74 & 11,7 & & II & 1 & 5,1 \\
\hline \multirow{2}{*}{ April } & 1 & 77 & 11,3 & \multirow{2}{*}{ Oktober } & $\mathrm{I}$ & 1 & 5,9 \\
\hline & II & 30 & 11,4 & & II & 15 & 6,1 \\
\hline \multirow{2}{*}{ Mei } & 1 & 7 & 5,6 & \multirow{2}{*}{ November } & 1 & 55 & 12,1 \\
\hline & II & 3 & 5,4 & & II & 108 & 12,5 \\
\hline \multirow{2}{*}{ Juni } & 1 & 1 & 4,9 & \multirow{2}{*}{ Desember } & 1 & 120 & 12,3 \\
\hline & II & 15 & 4,4 & & II & 198 & 12,0 \\
\hline
\end{tabular}

Sumber: Hasil perhitungan

Hasil pemodelan debit aliran dengan menggunakan Model Mock menghasilkan variasi debit rata-rata setengah bulanan $(Q)$ yang kecil, yakni dengan debit minimum $12,57 \mathrm{~m}^{3} / \mathrm{s}$ dan maksimum $17,55 \mathrm{~m}^{3} / \mathrm{s}$. Debit yang dihasilkan adalah debit rata-rata setengah bulanan yang dihasilkan oleh debitdebit yang lebih besar dan debit-debit yang lebih kecil yang terjadi selama setengah bulan.

Hasil analisis ini menghasilkan nilai faktor kendala seperti nampak pada Tabel 3. Gambar 6 menunjukkan bahwa Baseflow memiliki peran yang dominan dalam mensuplai ketersediaan air permukaan di DAS Juwet. Gambar 7 menunjukkan bahwa hasil analisis model dan pencatatan yang dihasilkan memiliki perbedaan yang tidak cukup besar. Hal ini juga nampak dari nilai uji t yang menghasilkan nilai lebih kecil dibandingkan dengan nilai $t$ tabel. Berdasarkan hasil perhitungan, diketahui bahwa ketersediaan debit aliran di DAS Juwet dengan probabilitas $80 \%$ selama satu tahun adalah sebesar 43 juta meter kubik. 


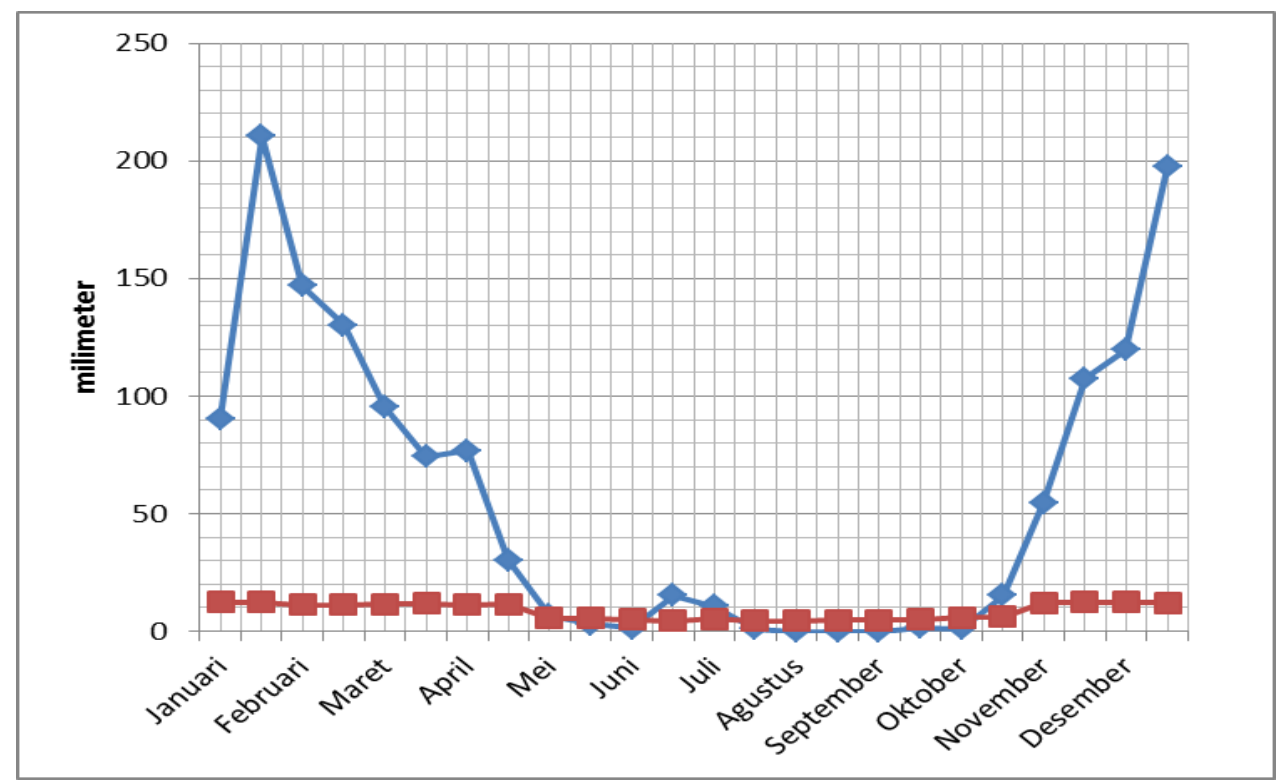

Gambar 5. Grafik hujan dan evapotranspirasi aktual di DAS Juwet

Tabel 3. Faktor Kendala Model Mock di DAS Juwet

\begin{tabular}{|c|c|c|}
\hline Parameter DAS & Simbol & Nilai Awal \\
\hline $\begin{array}{c}\text { Koefisien Infiltrasi Musim } \\
\text { Penghujan }\end{array}$ & WIC & 0,10 \\
\hline $\begin{array}{c}\text { Koefisien Infiltrasi Musim } \\
\text { Kemarau }\end{array}$ & DIC & 0,35 \\
\hline $\begin{array}{c}\text { Kelembaban Tanah Awal } \\
\text { (mm) }\end{array}$ & ISM & 50 \\
\hline Kapasitas Lapang (mm) & SMC & 100 \\
\hline $\begin{array}{c}\text { Tampungan Airtanah Awal } \\
\text { (mm) }\end{array}$ & IGWS & 2000 \\
\hline Koefisien Resesi & K & 0,75 \\
\hline
\end{tabular}

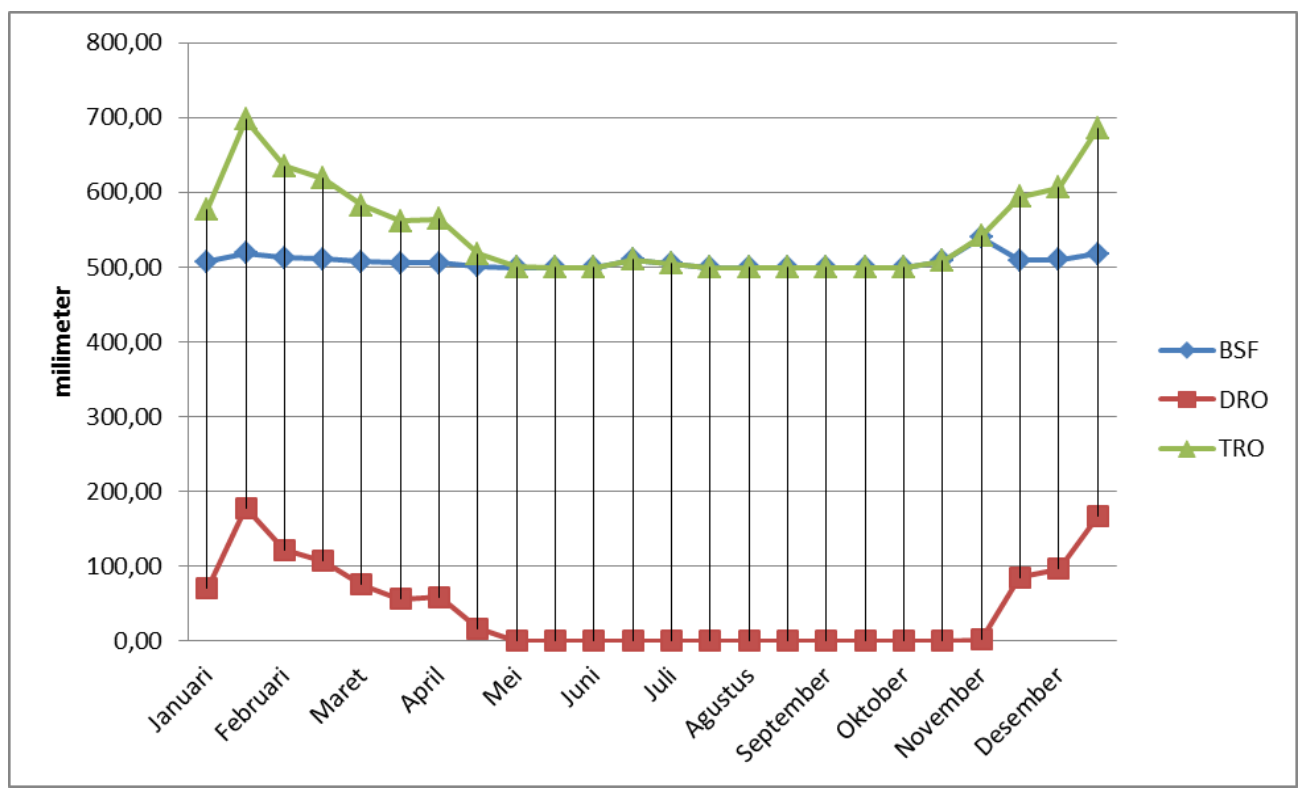

Gambar 6. Peranan Baseflow yang Besar di DAS Juwet 


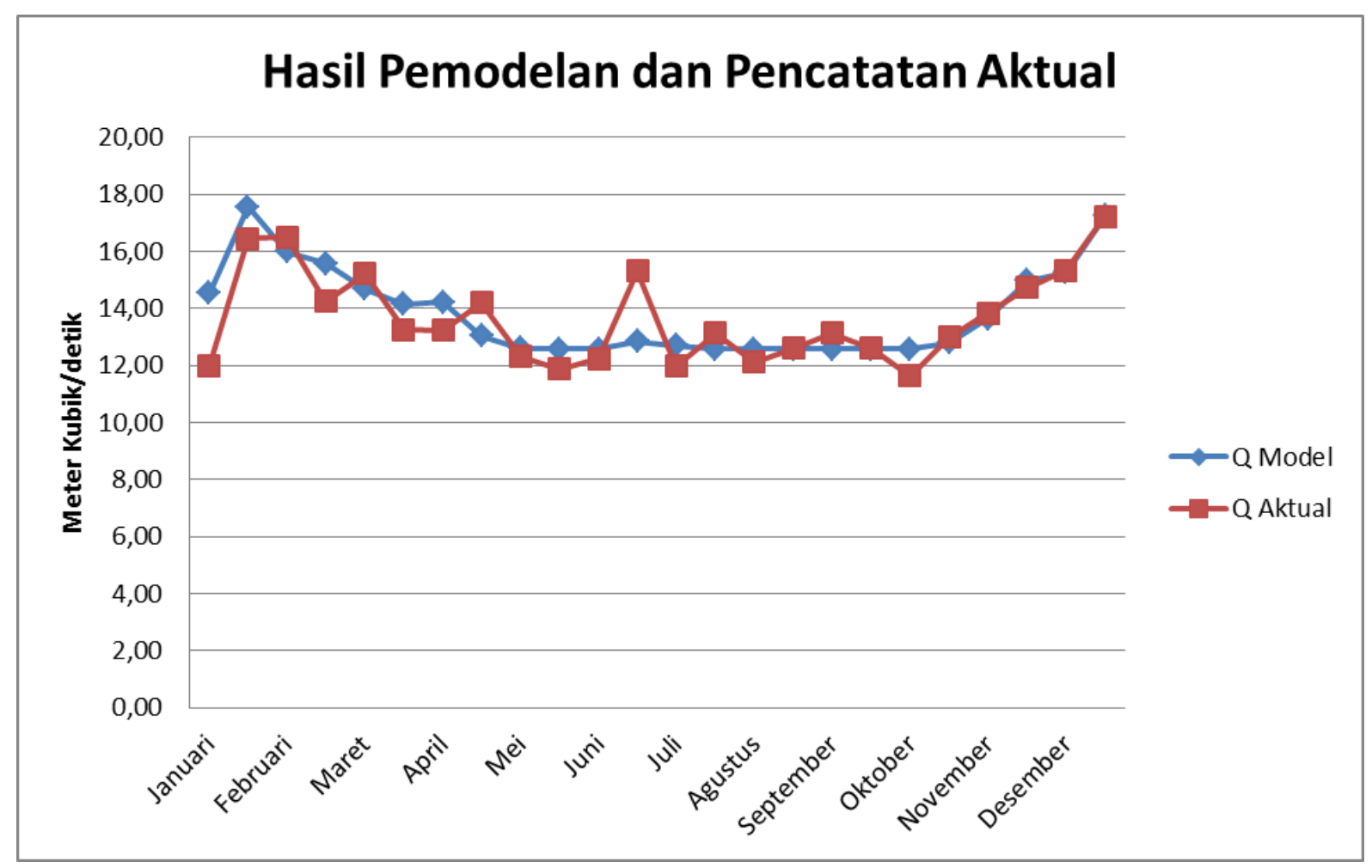

Gambar 7. Perbandingan Hasil Perbandingan Model Mock dan Hasil Pencatatan

\section{Kesimpulan}

Hasil analisis perhitungan ketersediaan air di DAS Juwet menggunakan Model Mock mengahasilka nilai ketersediaan air pada probabilitas $80 \%$ adalah sekitar 43 juta meter kubik. Meskipun telah dilakukan pemodelan, untuk kepentingan perencanaan yang lebih baik suatu DAS tetap memerlukan suatu SPAS.

\section{Daftar Pustaka}

Asdak, Chay. 2007. Hidrologi dan Pengelolaan Daerah Aliran Sungai Edisi IV. Yogyakarta: Gadjah Mada University Press.

Cahyadi, A.; Priadmodjo, A. dan Yananto, A. 2011. Criticizing The Conventional Paradigm of Urban Drainage. Proceeding The $3^{\text {rd }}$ International Graduated Student Conference on Indonesia. Yogyakarta, 8-9 November 2011. Hal: 547-553.

Sosrodarsono, S. 1977. Hidrologi untuk Pengairan. Jakarta: Pradnya Paramita.

Soil Survei Staff. 1998. Kunci Taksonomi Tanah. Edisi Kedua Bahasa Indonesia. 1999. Bogor:

Pusat Penelitian Tanah dan Agroklimat Badan Penelitian dan Pengembangan Pertanian.

Sudarmadji; Suprayogi, S. dan Setiadi. 2012. Konservasi Mata Air Berbasis Masyarakat di Kabupaten Gunungkidul. Yogyakarta: Penerbit Sekolah Pascasarjana Universitas Gadjah Mada.

Sunjoto. 2009. Konsep Hamemayu Hayuning Bawono dalam Pengelolaan Sumberdaya Air

Berkelanjutan. Pidato Guru Besar Universitas Gadjah Mada Yogyakarta. 